\title{
COMMENTS
}

\section{UNILATERAL MODIFICATION OF EMPLOYMENT \\ HANDBOOKS: FURTHER ENGROACHMENTS \\ ON THE EMPLOYMENT-AT-WILL \\ DOCTRINE}

RICHARD J. PRATT†

\section{INTRODUCTION}

In the United States today, there exists a disparity in the rights and privileges of the American work force. Unionized workers enjoy tremendous job security, work benefits, and an array of statutory protections. Others, less fortunate, are worked and discharged at the whim of the employer. This latter group of employees, working under what is termed an "at-will" relationship, constitute a majority of the United States work force. Indeed, eighty-five percent of the present American work force-approximately eighty-three million people-are employed under the at-will doctrine. ${ }^{1}$ These non-unionized workers are discharged at a rate two times that of unionized employees. ${ }^{2}$ In all, some 1.4 million of these workers are terminated from their jobs each year. ${ }^{3}$

† A.B. 1988, Duke University; J.D. Candidate 1991, University of Pennsylvania. This Comment is dedicated to my parents. Special thanks go to Professor Clyde W. Summers and Naomi H. Milton.

${ }^{1}$ See U.S. BUREAU OF THE CENSUS, DEP'T OF COMMERCE, STATISTICAL ABSTRACT OF THE UNITED STATES: 1990, at 418 (table 687, union membership); id. at 378 (table 624, total workforce). These numbers reflect private sector employment and do not include government workers or military personnel. See id. at 395 (table 651, government employees); see also Baker, NLRA Section 8(a)(3) and the Search for A National Labor Policy, 7 HOFSTRA LAB. L.J. 71, 104 n.121 (1989) (noting that 12.9 percent of "all private nonagricultural wage and salary workers were members of unions . . . while 14.2 percent [of those same workers] were represented by unions"). 19 (1988).

${ }^{2}$ See Hames, The Current Status of the Doctrine of Employment-At-Will, 39 LAB. L.J. 19,

${ }^{3}$ See Maltby, The Decline of Employment At Will-A Quantitative Analysis, 41 LAB. L.J. 51,53 (1990). As many as one million employees are discharged by private industry annually without a fair hearing. See Abbassi, Hollman \& Murrey, Employment at Will: An Eroding Concept in Employment Relationships, 38 LAB. L.J. 21, 21 (1987). Estimates suggest that as many as 200,000 of these at-will employees are wrongfully discharged each year. See id. 
This disparity in employment environments obviously has a significant effect upon the at-will employee both psychologically and financially. Unfortunately, such a situation wreaks havoc not only upon the lives of these individual workers. Besides being an archaic and inequitable theorem of law, the at-will doctrine creates an adverse impact upon the employer and the economy at large.

Part I of this Comment examines the history of the at-will doctrine as well as the traditional rationales which support its existence. Part II begiris by analyzing some recent tort and contractual erosions of the doctrine and then focuses upon a particular exception to at-will employment-the employment handbook as an implied contract. Part III traces the traditional analysis of employment handbooks. Finally, Part IV advocates adherence to the terms of the original handbook-as-contract in situations where employers distribute subsequent handbooks inconsistent with the rights and promises granted in the original.

\section{The At-Will PAST}

With the coming of the Industrial Revolution, major changes in the American work place were to alter forever the simple relations between "master" and "servant" and the laws which regulated them. Prior to the era of large-scale industry, mass employment, and capital accumulation, employment relations were of little importance in the common law. ${ }^{4}$ With burgeoning nineteenth century industry and its ever-increasing demand for labor, however, the need for flexible employment arrangements and unhampered managerial prerogative soon had an impact upon the development of the common law. ${ }^{5}$ Gone were the traditional duties under master-servant law, where the employer took responsibility for the servant's health and well-being. ${ }^{6}$ Gone, too, was the presumption that any employment was for a yearly term. ${ }^{7}$ In the place of these more traditional rules came the impersonal, arms-length theories of "assumption of risk" and "freedom of contract." 8 It was this latter

${ }^{4}$ See H. PERRITT, EMPLOYEe DISMISSAL LAW AND PRACTICE 2 (1984).

${ }^{5}$ See id. at 3.

${ }^{6}$ See Note, Employment At-Will-The Implied Contract Limitation in Arizona-Leikvold v. Valley View Community Hospital, 141 Ariz. 544, 688 P.2d 170 (1984), 16 ARIZ. ST. L.J. 783, 786 (1985).

${ }^{7}$ See id.

${ }^{8}$ See H. PERRTr, supra note 4, at 4; Note, supra note 6, at 786; Note, Protecting At Will Employees Against Wrongful Discharge: The Duty to Terminate Only in Good Faith, 93 HARV. L. REV. 1816, 1825-26 (1980). 
theory that would have a particularly significant influence on the legal system and the system's treatment of employment.

The principle of freedom of contract augmented the abilities of both employers and employees to determine independently their economic relationship. Nothing was to be assumed about the employment relationship. Absolute freedom of contract meant that there could be no presumptions about duration of employment, wages, or working conditions. ${ }^{9}$ For example, if an employee failed to secure an express provision concerning duration or some other aspect of her working situation, she was left without legal recourse. ${ }^{10}$ This preference for freedom of contract over any presumption of employment terms found its most popular enunciation in a legal treatise by H.G. Wood in $1877 . .^{11}$ In $A$ Treatise on the Law of Master and Servant, Professor Wood announced what he perceived to be the "American Rule":

With us the rule is inflexible, that a general or indefinite hiring is prima facie a hiring at will, and if a servant seeks to make it out a yearly hiring, the burden is upon him to establish it by proof. A hiring, at so much a day, week, month or year, no time being specified, is an indefinite hiring, and no presumption attaches that it was for a day even, but only at the rate fixed for whatever time the party may serve. ... [I]t is an indefinite hiring and is determinable at the will of either party ....12

Though modern historians have noted that Wood's analysis articulated a distinct departure from earlier American case law ${ }^{13}$ and that the four cases Wood cited as authority embraced no such proposition, ${ }^{14}$ the American judiciary soon seized upon the "American Rule"15 as a cornerstone of employment law. ${ }^{16}$ Any employment not for a definite term was presumed to be "at-will," meaning that the relationship could be terminated at the will of

${ }^{9}$ See H. PERRTT, supra note 4 , at 5.

${ }^{10}$ See Note, supra note 8 , at 1819 \& nn.16-17.

$11 \mathrm{H}$. WOOD, A TREATISE ON THE LAW OF MASTER AND SERVANT (1877).

12 Id. at 272.

${ }^{13}$ See Committee Reports: At-Will Employment and the Problem of Unjust Dismissal, 36 RECORD OF THE ASS'N OF THE BAR OF THE CITY OF NEW YORK 170, 172 (1981); Summers, Individual Protection Against Unjust Dismissal: Time For a Statute, 62 VA. L. REv. 481, 485 (1976).

${ }^{14}$ See H. PERRIT, supra note 4, at 6.

${ }^{15}$ This Comment uses the term "American Rule" interchangeably with the concept of at-will employment.

${ }^{16}$ See sources cited supra note 13. 
either party. ${ }^{17}$ Reduced to its barest essentials, the at-will doctrine permitted employees to quit their jobs at any time, ${ }^{18}$ and allowed employers to discharge their employees at any time-for good reason, bad reason, or no reason at all. ${ }^{19}$

While the at-will doctrine may have nurtured nascent American industry, its appearance and continued presence has not proved as beneficent for the American worker. While the doctrine's neutral wording implies that an employer and employee should be able to bargain to some sort of mutually satisfactory arrangement, the doctrine ignores the practical realities that few workers are skilled and mobile enough simply to quit their employment if dissatisfied. ${ }^{20}$ Fewer workers still are in a position to exact significant contractual concessions on an individual basis. ${ }^{21}$ The result of such employee impotence is employee vulnerability. The at-will doctrine has permitted firings in situations where employees have merely filed workmen's compensation and unemployment claims, reported illegal activities committed by the employer, reported for jury duty, refused the sexual advances of the employer, refused to support the political candidates advocated by the employer, or refused to take psychological tests. ${ }^{22}$ The doctrine allows employers to fire employees for visiting stores the employer declares offlimits, ${ }^{23}$ and allows employers to fire thirty-year employees days before their pensions vest. ${ }^{24}$ Such egregious decisions are the

17 See Note, supra note 6, at 786.

${ }^{18}$ See DeGiuseppe, The Effect of the Employment-At-Will Rule On Employee Rights to Job Security and Fringe Benefits, 10 FORDHAM URB. L.J. 1, 8 \& n.24 (1981). As one court stated, "An employee is never presumed to engage his services permanently, thereby cutting himself off from all chances of improving his condition; indeed, in this land of opportunity it would be against public policy and the spirit of our institutions that any man should thus handicap himself ...." Pitcher v. United Oil \& Gas Syndicate, Inc., 174 La. 66, 67, 139 So. 760, 761 (1932).

${ }^{19}$ See, e.g., Payne v. Western \& Atl. R.R. Co., 81 Tenn. 507, $519-20$ (1884), overnuled on other grounds, Hutton v. Watters, 132 Tenn. 527, 179 S.W. 134 (1915).

${ }^{20}$ See infra text accompanying notes 29-33. Especially in an age of increasing specialization and bias against older workers, as well as unemployment, worker mobility and hence ability to terminate employment is significantly reduced. For a discussion on the impotence and insecurity of the modern day non-unionized employee vis-à-vis the at-will doctrine, see generally Elades, Employment At-Will vs. Individual Freedom: On Limiting The Abusive Exercise of Employer Power, 67 CoLuM. L. REv. 1404 (1967) (arguing that since the great majority of employees are viewed as fungible, most non-unionized employees are not able to extract individually negotiated contracts from their employers).

${ }^{21}$ See Blades, supra note 20, at 1411.

22 See DeGiuseppe, supra note 18, at 9-10.

${ }^{23}$ See Payne, 81 Tenn. at 519-20.

${ }^{24}$ See Murphy v. American Home Products Corp., 58 N.Y.2d 293, 307, 448 N.E.2d 
result of a widespread judicial dogmatism in the employment law context. The at-will rule has become, in many instances, an irrebuttable rule of law that indeed countenances a firing for any reason. ${ }^{25}$

\section{Dissatisfaction With The At-Will Rule}

The at-will doctrine (or American Rule) was a by-product of the booming economic times in which it was born. The American Rule increased an employer's freedom in the employment relationship while it concomitantly limited her responsibilities and duties. ${ }^{26}$ By enabling the employer to adapt her work force to any circumstance by terminating any undesirable or unproductive employee, the atwill doctrine contributed to the entrepreneurship and economic growth of an era. ${ }^{27}$

Yet, in the past quarter century, a rising tide of criticism has swelled against the at-will doctrine and its harsh effects upon the employee. ${ }^{28}$ The imbalance in the relationship between employer and employee, a factor that led to the increase in labor unionism over fifty years ago, ${ }^{29}$ has sparked sharp criticism throughout the legal community. Scholars have noted that in the modern era, employees' comparative immobility is exacerbated by the narrowing of alternative job opportunities resulting from technological advances which require increased job specialization. Employees' jobs have thus become increasingly precious. ${ }^{30}$ The importance of retaining one's job effectively eliminates many employees' ability to leave their jobs. Consequently, employees' emphasis on job retention, coupled with the employer's absolute power to fire anyone for any reason, has been viewed as a recipe for significant abuse. Apart from the sheer injustice of allowing employers to discharge employees for insignificant or non-existent reasons, the at-will doctrine has been faulted for creating a climate conducive to

86, 93, 461 N.Y.S.2d 232, 239 (1983) (Meyer, J., dissenting in part).

${ }^{25}$ See Blades, supra note 20, at 1416; see also Note, The Employment Handbook as a Contractual Limitation On The Employment At Will Dotrine, 31 VILI. L. REV. 335, 339 (1986).

${ }^{26}$ See Note, supra note 8 , at 1826.

${ }^{27}$ See DeGiuseppe, supra note 18, at 7; Note, Employee Handbooks and Employment-AtWill Contracts, 1985 DuKE L.J. 196, 198; Note, supra note 8, at 1826.

${ }^{28}$ See Note, supra note 27, at 198. See generally Blades, supra note 20.

${ }^{29}$ See Blades, supra note 20, at 1404-05.

${ }^{30}$ See id. at 1405 . 
employer coercion. ${ }^{31}$ The doctrine arguably fosters an employment relationship in which an employee's fear of discharge easily renders her vulnerable to any overreaching demands made by the employer. ${ }^{32}$ This concern--that employees will be intimidated into illegal or unsafe activity-has unfortunately proven to be more than speculative. ${ }^{33}$

The at-will doctrine also has been criticized for a larger ill effect upon the economy as a whole. Both commentators ${ }^{34}$ and courts $^{35}$ recognized belatedly that the American Rule may in fact have a negative impact on industrial efficiency. Because job security can improve economic performance by increasing worker loyalty, productivity, and inventiveness while reducing turn-over and training costs, absenteeisrn, and sabotage, the at-will doctrine's raison d'être itself is impeached. ${ }^{36}$

In recent decades, the widespread dissatisfaction in the legal community with the at-will doctrine has resulted in the development of various theories and approaches which, to one degree or another, cut serious inroads into what was once an "absolute presumption" in favor of at-will employment. ${ }^{37}$ Perhaps the most drastic approach has been the call for a complete rejection of the doctrine. In its stead opponents argue for a "just cause" statute that would cover every worker and would function like the grievance process that has proved so successful in the unionized labor arbitration arena. ${ }^{38}$ While such a call has not gone entirely unheeded, ${ }^{39}$ it

${ }^{31}$ See id. at 1406-07.

${ }^{32}$ See id. at 1407-08 \& n.11 (discussing dismissal as the organizational equivalent of "economic capital punishment").

${ }^{33}$ See, e.g., id. at $1408 \mathrm{nn} .17-18,1409 \mathrm{n} .22$ (describing employees who were forced by their employers to carry on illegal activities and noting specific instances in which employees were threatened with dismissal if they did not carry out an illegal or unsafe activity).

${ }^{34}$ See, e.g., Note, supra note 8, at 1830-36 (suggesting abandonment of the at-will rule because it is economically inefficient).

${ }^{35}$ Courts have also recognized that an unqualified application of the at-will doctrine would negatively effect the economic system. See Fulford v. Burndy Corp., 623 F. Supp. 78, 80 (D.N.H. 1985); Monge v. Beebe Rubber Co., 114 N.H. 130, 133, 316 A.2d 549, 551 (1974).

${ }^{36}$ See Bahrami, Productivity Improvement Through Cooperation of Employees and Employers, 39 LAB. L.J. 168, $171-72$ (1988); Note, supra note 8, at 1835; Note, Challenging The Employment-At-Will Doctrine Through Modern Contract Theory, 16 U. MICH. J.L. REF. 449, 453-55 (1983).

${ }^{37}$ See Note, supra note 25 , at $338-39$.

${ }^{98}$ See Summers, supra note 13, at 519-31 (arguing that a statute should be enacted which articulates the right of employees not to be disciplined except for "just cause" and channels the adjudication of cases arising under the statute into arbitration); see also 
is apparently too novel for many present day legislatures. ${ }^{40}$ Today, more scholarship and judicial acceptance has focused on emerging contractual and tort claims favoring the employee. This series of innovative claims, singly and in sum, represent a major carving out of exceptions to, and exemptions from, the at-will doctrine.

In tort, the theory most widely used to mitigate the harsh effects of the at-will doctrine is the public policy exception. Where a discharge by an employer is found to be injurious to a clearly articulated public good or policy, courts have often recognized a tort of wrongful discharge based on public policy grounds. ${ }^{41}$ Other tort theories that have provided a measure of relief from the at-will discharge are the prima facie tort ${ }^{42}$ and the tort of intentional infliction of emotional distress. ${ }^{43}$

Contract theories have also been utilized by the aggrieved employee to mitigate the American Rule. Courts are often willing to remove a case from the ambit of the at-will doctrine when an employee can show, apart from his usual services, valid additional consideration in return for an employer's promise of benefits or just

Perritt, Wrongful Dismissal Legislation, 35 UCLA L. REv. 65, 98 (1987) (suggesting that an enumerated prohibitions approach to wrongful dismissal legislation is politically more feasible than a simple just cause approach).

${ }^{39}$ See MONT. CODE ANN. §§ 39-2-902 to-914 (1987) (Montana's Wrongful Discharge from Employment Act).

40 See Note, supra note 25 , at 343 n.37. (describing the Pennsylvania state legislature's consideration and rejection of a bill to provide all employees with a grievance process when dismissed without just cause).

41 See, e.g., Boyle v. Vista Eyewear Inc., 700 S.W.2d 859, 878 (Mo. Ct. App. 1985) (holding that plaintiff-employee stated a cause of action in tort for wrongful discharge in alleging that employer fired her for threatening to report company's unlawful activities to the Food and Drug Administration); see also DeGiuseppe, supra note 18, at 30-34 (noting that an aggrieved employee carries the burden of proof that her employer violated the public policy of a particular state in effectuating her discharge); Note, Ravelo v. County of Hawaii: Promissory Estoppel and the Employment At-Will Doctrine, 8 U. HAW. L. REv. 163, 169 (1986) (noting that courts generally recognize the tort of wrongful discharge when termination by the employer is found to have violated public policy).

${ }^{42}$ See DeGiuseppe, supra note 18 , at $42-43$. The prima facie tort is defined as an "infliction of intentional harm, resulting in damage, without excuse or justification, by an act or series of acts which would otherwise be lawful." Ruzza v. Ruzza, 286 A.D. 767, 769, 146 N.Y.S.2d 808, 811 (1955), quoted with approval in ATI, Inc. v. Ruder \& Finn, Inc., 42 N.Y.2d 454, 458, 368 N.E.2d 1230, 1232 (1977).

43 See, e.g., Pratt v. Brown Machine Co., 855 F.2d 1225, 1238-39 (6th Cir. 1988) (holding that in order to make out a prima facie case of intentional infliction of emotional distress, plaintiff must establish: (1) extreme and outrageous conduct; (2) intent or recklessness; (3) causation; and (4) severe emotional distress); see also DeGiuseppe, supra note 18, at 40-42. 
cause dismissal. ${ }^{44}$ Without such additional consideration, however, such promises are mere gratuities, non-binding because of their lack of consideration. The traditional notion of promissory estoppel has also been used to protect an employee's reliance interest. By showing a court that the employee reasonably relied to her detriment on the employer's gratuitous promise, ${ }^{45}$ the employee can seek recovery "if injustice can be avoided only by enforcement of the promise." ${ }^{46}$

The employment handbook (also called an employer handbook or personnel policy manual), distributed by the employer and often laced with explicit and implicit promises, constitutes yet another exception to the employment at-will doctrine. This implied contract exception, and its ramifications, will comprise the crux of this Comment. ${ }^{47}$

Yet, before turning to the employee handbook in depth, it should be emphasized that the above exceptions to the at-will doctrine are quite recent developments, resulting from a discerning judiciary which has begun to cast a critical eye upon the American Rule. ${ }^{48}$ Commentators not so long ago were saturnine about the assailability of the at-will doctrine, ${ }^{49}$ but the emerging erosion of the doctrine-largely a reflection of courts' concern with the

${ }^{44}$ See Note, supra note 41, at 169-70; see also Ohnian v. Avis Rent A Car Sys., 779 F.2d 101, 109 (2d Cir. 1985) (stating that plaintiff's relocation from San Francisco to New York was sufficient considerarion for a promise of lifetime employment); Bravman v. Bassett Furniture Indus., 552 F.2d 90, 93-94 (3d Cir. 1977) (stating that a furniture seller who forgoes representation of other manufacturers renders sufficient consideration to support a jury's conclusion that his contract with the defendant manufacturer was not terminable at will); Stauter v. Walnut Grove Prod., 188 N.W.2d 305, 312 (lowa 1971) (stating that selling a competitive business to the employer was additional consideration for a lifetime employment contract); $c f$. Weiner v. McGraw-Hill, Inc., 57 N.Y.2d 458, 464-65, 443 N.E.2d 441, 445, 457 N.Y.S.2d 193, 197 (1982) (stating that a detriment to a promisor need not benefit the promisee to serve as consideration).

${ }^{45}$ Such a promise could be for full employment or of a just-cause termination nature. It could also include more specific promises covering seniority and lay-off assurances.

${ }^{46}$ For the full text of the RESTATEMENT (SECOND) OF CONTRACTS definition of promissory estoppel, see infra text: accompanying note 116. Courts are increasingly willing to apply promissory estoppel doctrine. See Comment, Employment At-Will and the Law of Contracts, 33 BUFFALO I. REv. 211, 232 (1974). Courts seem particularly willing to apply the doctrine where parties have an ongoing relationship, and trustworthiness and reliability are necessary in such dealings. The employment relationship is one example. See Farber \& Matheson, Beyond Promissory Estoppel: Contract Law and the Invisible Handshake, 52. U. CHI. L. REV. 903, 925-26 (1985).

${ }^{47}$ See infra notes 56-124 and ar:companying text.

48 See DeGiuseppe, supra note 18, at 23; Note, supra note 41, at 168.

49 See Blades, supra note 20, at 1421; DeGiuseppe, supra note 18 , at 3, 9-10. 
doctrine's harsh effects-suggests that the judicial community is now willing to reevaluate the employment relationship. ${ }^{50}$ While some courts continue to cling dogmatically to the broad-brush simplicity of the at-will rule, other more "progressive"51 courts have recognized that the doctrine should not be viewed as stark and absolute. These progressive courts properly interpret the at-will rule as a rule of construction that merely aids courts in construing the relationship between employer and employee. ${ }^{52}$ As commentators ${ }^{53}$ and courts $^{54}$ alike have noted, the at-will rule was created and endorsed by the bench; it can just as appropriately be modified by the bench:

The employment-at-will rule is not set indelibly in stone. It is a part of the common law judicially created, and within the power of judicial reform. Thus, there is no reason to treat it as though it has the strength of legislation. .. " Inherent in the common law is a dynamic principle which allows it to grow and to tailor itself to meet changing needs. . . . If this were not so, we must succumb to a rule [stare decisis] that a judge should let others 'long dead and unaware of the problems of the age in which he lives, do his thinking for him'...."

${ }^{50}$ See Note, supra note 8, at 1824; Note, supra note 41, at 168-72.

${ }^{51}$ I use the traditional-progressive delineation recognized by other commentators. See, e.g., Note, supra note 27, at 196. "Traditional" is meant to imply a more doctrinaire, conservative approach to the at-will rule while a "progressive" appellation suggests a philosophical willingness to re-examine the rule in modern contexts against developing theories of law. Judges themselves often view exceptions to the at-will rule as "progressive." See, e.g., Small v. Springs Indus., Inc., 292 S.C. 481, 486, 357 S.E.2d 452, 455 (1987) ("South Carolina, as a progressive state which wishes to see that both employer and employee are treated fairly, now joins those states [recognizing the employment handbook as an alteration to employment-at-will].").

52 See, e.g, Thompson v. Kings Entertainment Co., 653 F. Supp. 871,873 (E.D. Va. 1987) (noting that "[u]nder Virginia law, a general hiring where the term of employment is not specified is presumed to be terminable at-will," though this presumption may be rebutted); Toussaint v. Blue Cross \& Blue Shield, 408 Mich. 579, 596-97, 292 N.W.2d 880, 884 (1980) (noting that the general rule that a contract for indefinite employment is terminable at will is not "a substantive limitation on the enforceability of employment contracts but merely a rule of 'construction'"); Pine River State Bank v. Mettille, 333 N.W.2d 622, 628 (Minn. 1983) (explaining that the at-will rule is only a rule of contract construction, imposing substantive limits to the formation of a contract, but not preventing parties from providing for job security provisions in an employment contract of an indefinite duration).

${ }_{53}$ See, e.g., Note, supra note 8, at 1838 (asserting that "[c]ourts themselves created the at will rule; it is therefore entirely appropriate that they now take the lead in modifying it").

54 See Meeks v. Opp Cotton Mills, Inc., 459 So. 2d 814, 816 (Ala. 1984).

${ }^{55} \mathrm{Id}$. (quoting Lewis v. Wolf, 122 Ariz. 567, 568, 596 P.2d 705, 706 (1979), overruled, Ontiveros v. Borak, 136 Ariz. 500, 508, 667 P.2d 200, 208 (1983)). 
With this framework of change and fresh perspective, we turn to the employee handbook exception to the employment-at-will doctrine.

\section{EMPloyeE HaNDboOKS: ThE TRAdITIONAL ANALYSIS}

For decades, employers have promulgated company policies and rules through the medium of employee handbooks. ${ }^{56}$ Such manuals usually detail two types of formal rules: some are substantive, governing the employee's job and employment expectations, while others are procedural, describing the granting of employee benefits. ${ }^{57}$ Handbooks may contain only vague policy statements, or they may contain explicitly defined provisions concerning termination procedures, severance pay, wages, or vacation and pension plans. ${ }^{58}$ Depending upon the employer, handbooks are frequently used and adhered to during the course of employment, although some employers disseminate handbooks and subsequently pay little attention to them. ${ }^{59}$ Most employers who use handbooks issue such manuals to employees at the time of hiring, ${ }^{60}$ but first edition employment handbooks are not uncommonly distributed to a work force that has been. employed for years. ${ }^{61}$ Some employers require each employee to read and sign her manual. ${ }^{62}$

In the past and in some jurisdictions today, where the at-will doctrine remains an insuperable substantive rule of law, ${ }^{63}$ an employers' oral or written promises are never binding unless the employee supplies additional consideration beyond her usual services. ${ }^{64}$ Under principles of consideration and mutuality that were dominant in the nineteenth and much of the twentieth centuries, traditional contract notions prevented any other conclusion: employees received wages in exchange for labor and services. ${ }^{65}$ If

${ }^{56}$ See H. PERRITT, supra note 4 , at 303-06.

${ }^{57}$ See id. at 309.

${ }^{58}$ See Comment, The Vestiges of the Texas At-Will Doctrine in the Wake of Progressive Law: The Employment Handbook Erception, 18 ST. MARY's L.J. 327, 334-35 (1986).

${ }^{59}$ See id. at 335.

${ }^{60}$ See id. at 334.

61 See, e.g., Brookshaw v. South St. Paul Feed, Inc., 381 N.W.2d 33, 34 (Minn. App. 1986) (noting that employee worked for fifteen years before handbook was written and distributed); Small v. Springs Indus., Inc., 292 S.C. 481, 483, 357 S.E.2d 452, 453 (1987) (noting that plaintiff was employed for five years before company distributed a personnel manual).

${ }^{62}$ See Comment, supra note 58, at 335-36.

${ }^{63}$ See id.

64 See Note, supra note 27 , at $2: 00-01$.

${ }^{65}$ See Note, supra note 25 , at $\$ 51$. 
an employee wished to make any aspect of her employment relationship binding, she was required to furnish the employer with additional consideration. ${ }^{66}$ Thus, for example, if an employee wanted to make a promise of "just cause" discharge enunciated in a handbook binding, under traditional contract analysis she would have to supply her employer with some benefit beyond her ordinary work product. This is because her work is already being compensated by her wages.

Under this traditional approach to the at-will doctrine, both employer and employee receive a benefit from the employment relationship, but neither is bound by it. The dissemination of an employment handbook with just cause provisions should in no way change the relationship. To require that a handbook be binding without additional consideration would, under traditional analysis, mean that an employer would be obligated to follow stated dismissal procedures that she announced without any benefit in return. The procedures would be binding on the employer, while the employee would continue to enjoy the freedom of quitting at any time. Therefore, courts applying traditional notions of contract and the employment-at-will doctrine have continued to maintain that if an employment manual is to be interpreted as a contract, additional consideration from the employee is necessary. ${ }^{67}$

The above discussion implicates another traditional impediment to the handbook as contract: the doctrine of mutuality. Courts that utilize the traditional analysis further support their theory of consideration by stressing the unilateral nature of the employment manual. The employment handbook, these courts contend, is nothing more than a unilateral expression of company policy. Aside from the fact that the handbook represents an unbargained-for gratuitous statement by the employer with no employee consideration to make it binding, all formulation and codification of the policies within are controlled by the employer. Since the employer drafts and issues the handbook without employee input or ratification (i.e., no meeting of the minds), it is difficult to insist that such handbooks embody any mutual obligation on the part of the employee. ${ }^{68}$ "[W] any agreement imposing a duty on the employer as to the employee's term[s] of employment lacks mutuality of obligation, and

\footnotetext{
${ }^{66}$ See id.

${ }^{67}$ See Comment, supra note 58, at 343-44; Note, supra note 25, at 350-52.

${ }^{68}$ See Comment, supra note 58 , at 344-45.
} 
hence, the employment is [still] for an indefinite period and is terminable at will." ${ }^{n 9}$ In sum, the doctrine of mutuality rejects binding an employer to the promises of an employment manual because the employee remains free to quit her employment at any moment for any reason. ${ }^{70}$

Although the doctrines of consideration and mutuality prove fatal to any interpretation of handbook manuals as implied contracts under a traditional analysis, such a dogmatic approach is becoming increasingly rare in the United States. ${ }^{71}$ More progressive courts, in response to the harsh effects of the at-will doctrine, are insisting on a re-appraisal of the doctrine. ${ }^{72}$ In these courts, employmentat-will is no longer a substantive rule. Instead, it is understood as a mere rule of construction which is subject to amendment. ${ }^{73}$

\section{Amendirg The At-Will Doctrine}

Even though as recently as 1981 labor commentators could credibly assert that most American courts would not regard employment manuals as implied contracts, ${ }^{74}$ the tide in this area of law has since radically shifted.$^{75}$ At least thirty-three states and the District of Columbia now recognize that specific promises embodied in personnel handbooks may be binding upon employers. ${ }^{76}$ These courts have arrived at their holdings via two avenues.

${ }^{69}$ Note, supra note 25 , at 352.

${ }^{70}$ See Note, supra note 27, at 2.02.

71 See Comment, supra note 58 , at 336.

72 See Note, supra note 27, at 2:09; Comment, supra note 58, at 342.

${ }^{73}$ See supra notes 51-55 and accompanying text; see also Note, supra note 27, at 211 12 (asserting that progressive courts view the doctrine of employment-at-will "as a rule of construction, rather than one of substance"); Comment, supra note 58, at 340-43 (citing Toussaint v. Blue Cross \& Blue Shield, 408 Mich. 579, 292 N.W.2d 880 (1980), where the court rejected the view that employment-at-will constituted a substantive rule of law rather than a rule of construction); Note, supra note 25, at 340 (claiming that the number of courts willing strictly to apply the employment-at-will doctrine has greatly declined in favor of a rebuttable presumption of employment-at-will).

74 See DeGiuseppe, supra note 18 , at $44-45$.

75 See, e.g., Note, supra note 27, at 199-200 (describing the courts' recent approach to employment manuals as "part of the general erosion of the employment-at-will doctrine"); Comment, Labor Law-Eimployment At Will Doctrine, 17 RUTGERs L.J. 715, 72728 (1986) (noting that the majority of courts to address the issue in recent years have recognized that employment manuals may have binding effect).

${ }^{76}$ See Hoffmann-La Roche, Inc. v. Campbell, 512 So. 2d 725 (Ala. 1987); Jones v. Central Peninsula Gen. Hosp., 779 P.2d 783 (Alaska 1989); Leikvold v. Valley View Community Hosp., 141 Ariz. 544, 688 P.2d 170 (1984) (en banc); Gladden v. Arkansas Children's Hosp., 292 Ark. 130, 728 S.W.2d 501 (1987); Foley v. Interactive Data Corp., 47 Cal. 3d 654, 765 P.2d 373, 254 Cal. Rptr. 211 (1988); Churchey v. Adolph Coors Co., 
Some courts have undertaken a re-evaluation of consideration and mutuality and their effect on at-will employment, while other courts have relied upon the notion of promissory estoppel to make such handbooks binding. ${ }^{77}$ Both approaches are examined in turn.

\section{A. Unilateral Contract}

A major feature of the progressive courts is a willingness to examine the at-will doctrine afresh. While this re-examination is part of a larger repudiation of nineteenth century concepts in labor law, ${ }^{78}$ it is also a direct result of the unfair outcomes produced by mechanical applications of the American Rule. ${ }^{79}$ Progressive

759 P.2d 1336 (Colo. 1988) (en banc); Finley v. Aetna Life \& Casualty Co., 202 Conn. 190, 520 A.2d 208 (1987); Washington Welfare Ass'n v. Wheeler, 496 A.2d 613 (D.C. App. 1985); Shannon v. Huntley's Jiffy Stores, 174 Ga. App. 125, 329 S.E.2d 208 (1985); Nilsson v. Mapco, 115 Idaho 18, 764 P.2d 95 (1988); Duldulao v. Saint Mary of Nazareth Hosp. Center, 115 Ill. 2d 482, 505 N.E.2d 314 (1987); Cannon v. National By-Prod., 422 N.W.2d 638 (Iowa 1988); Libby v. Calais Regional Hosp., 554 A.2d 1181 (Me. 1989); Staggs v. Blue Cross, 61 Md. App. 381, 486 A.2d 798 (1985); Toussaint v. Blue Cross \& Blue Shield, 408 Mich. 579, 292 N.W.2d 880 (1980); Pine River State Bank v. Mettille, 333 N.W.2d 622 (Minn. 1983); Enyeart v. Shelter Mut. Ins. Co., 693 S.W.2d 120 (Mo. Ct. App. 1985); Meech v. Hillhaven W., Inc., 238 Mont. 21, 776 P.2d 488 (1989); Morris v. Lutheran Med. Center, 215 Neb. 677, 340 N.W.2d 388 (1983); Southwest Gas Corp. v. Ahmad, 99 Nev. 594, 668 P.2d 261 (1983); Woolley v. Hoffmann-La Roche, Inc., 99 N.J. 284, 491 A.2d 1257, modified, 101 N.J. 10, 499 A.2d 575 (1985); Forrester v. Parker, 93 N.M. 781, 606 P.2d 191 (1980); Hammond v. North Dakota State Personnel Bd., 345 N.W.2d 359 (N.D. 1984); Kelly v. Georgia-Pacific Corp., 46 Ohio St. 3d 134, 545 N.E.2d 1244 (1989); Langdon v. Saga Corp., 569 P.2d 524 (Okla. Ct. App. 1976); Swartout v. Precision Castparts Corp., 83 Or. App. 203, 730 P.2d 1270 (1986); Small v. Springs Indus., Inc., 292 S.C. 481, 357 S.E.2d 452 (1987); Osterkamp v. Alkota Mfg., 332 N.W.2d 275 (S.D. 1983); Hamby v. Genesco, Inc., 627 S.W.2d 373 (Tenn. App. 1981); Benoir v. Ethan Allen, Inc., 147 Vt. 268, 514 A.2d 716 (1986); Thompson v. St. Regis Paper Co., 102 Wash. 2d 219, 685 P.2d 1081 (1984) (en banc); Cook v. Heck's, Inc., 342 S.E.2d 453 (W. Va. 1986); Ferraro v. Koelsch, 124 Wis. 2d 154, 368 N.W.2d 666 (1985); Mobil Coal Producing v. Parks, 704 P.2d 702 (Wyo. 1985).

The state of New York has split decisions on the issue of handbooks as contracts. Compare Weiner v. McGraw Hill, Inc., 57 N.Y.2d 458, 466, 443 N.E.2d 441, 445, 457 N.Y.S.2d 193, 197 (1982) (holding that a handbook can be a contract) with Rizzo v. International Bhd. of Teamsters, Local 237, 109 A.D.2d 639, 641-42, 486 N.Y.S.2d 220, 221 (1985) (holding that a handbook is not a contract where the employee is unaware of its existence).

77 See Note, supra note 25 , at $350-51$.

${ }^{78}$ See Note, supra note 8 , at 1826.

79 See, e.g., Toussaint v. Blue Cross \& Blue Shield, 408 Mich. 579, 613, 292 N.W.2d 880,892 (1980) (noting that by creating an atmosphere in which an employee believes handbook policies and practices are official the employer has created a situation in which the employer should be bound); Comment, supra note 58, at 342 (noting that courts have turned to the intent of the parties to avoid the unfair results produced by a mechanical application of the rule). 
courts refuse to accept the employment-at-will doctrine as substantive law which must be followed. Rather, they argue against the formalistic examination of the contract to determine if employment is at-will. ${ }^{80}$ Hinging an entire decision in a wrongful discharge action solely on the fact that the employee was hired for an indefinite term, these courts assert, can lead to inequitable results. ${ }^{81}$

Many courts that find statements in employment manuals binding do so by utilizing unilateral contract analysis. ${ }^{82} \mathrm{~A}$ unilateral contract does not exhibit any bargaining process or exchange of promises by the parties. In a unilateral contract, only one party makes a promise (an offer) which invites performance by another. As such, performance constitutes acceptance of the offer and makes the promise binding. ${ }^{83}$ Authorities note that in unilateral contract analysis there is only one promisor and that performance constitutes consideration. ${ }^{84}$ It is important to note too that this single performance may furnish consicleration for multiple promises. ${ }^{85}$

Although unilateral contract theory may be inappropriate for analyzing complex, multi-party transactions, it has been widely deemed appropriate for employment and handbook scenarios. ${ }^{86}$ Handbooks, like oral assurances, can reasonably be viewed as specific offers by the employer. ${ }^{87}$ Such handbooks appear as

${ }^{80}$ Courts note Professor Wood's lack of support for his rule, and view the American Rule as nothing more than a rebuttable presumption. See supra notes 13-14 and accompanying text; cases cited supra note 52; see also Leikvold v. Valley View Community Hosp., 141 Ariz. 544, 546, 688 P.2d 170, 172 (1984) (en banc) (stating that employment-at-will is merely a rule of construction); Woolley v. Hoffmann-La Roche, Inc., 99 N.J. 284, 295, 491 A.2d 12.57, 1263 (stating that the American Rule is only one of construction), modified on other grounds, 101 N.J. 10, 499 A.2d 515 (1985); Weiner v. McGraw-Hill, Inc., 57 N.Y.2d 458, 466, 443 N.E.2d 441, 446, 457 N.Y.S.2d 193, 198 (1982) (holding that the at-will rule in New York is a rebuttable presumption).

81 See Comment, supra note 58, at 342.

82 See Pine River State Bank v. Mettille, 333 N.W.2d 622, 630 (Minn. 1983); Helle v. Landmark, Inc., 15 Ohio App. 3d 1, 10-12; 472 N.E.2d 765, 775-76 (1984); Small v. Springs Indus., Inc., 292 S.C. 481, 484, 357 S.E.2d 452, 454 (1987).

${ }^{83}$ See Helle, 15 Ohio App. 3d at 11, 472 N.E.2d at 775; Small, 292 S.C. at 484, 357 S.E.2d at 454; A. CORBIN, CORBIN ON CONTRACTS ONE VOLUME EDITION $\$ 21$, at 31-36, $\S 63$, at $102-03$ (1952).

${ }^{84}$ See Small, 292 S.C. at 484-85, 357 S.E.2d at 454; A. CORBIN, supra note 83, § 21 at 54; see also J. Cal_amari \& J. Pelullo, THE LAW of ConTRACTs $\$ 2-10$ (3d ed. 1987).

${ }^{85}$ See Helle, 15 Ohio App. 3d at 11, 472 N.E.2d at 775; RESTATEMENT (SECOND) OF CONTRACTS $\$ 80$ comment a (1979).

${ }^{86}$ See cases cited supra note 82.

87 See, e.g., Helle v. Landmark, Inc., 15 Ohio App. 3d 1, 9, 472 N.E.2d 765, 774 (1984) (holding that a severance plan in manual, coupled with oral assurances, could be viewed as an offer); Small v. Spring Ind., Inc., 292 S.C. 481, 484, 357 S.E.2d 452, 454 
official statements by the employer and are promulgated for her benefit. $^{88}$ Many courts have vigorously rejected management contentions that handbooks are mere gratuities, since such an interpretation makes handbook promises illusory: ${ }^{89}$

[There are] "strong equitable and social policy reasons militating against allowing employers to promulgate for their employees potentially misleading personnel manuals while reserving the right to deviate from them at their own caprice." ... It is patently unjust to allow an employer to couch a handbook, bulletin, or other similar material in mandatory terms and then allow him to ignore these very policies as "a gratuitous, non-binding statement of general policy" whenever it works to his disadvantage. Assuredly, the employer would view these policies differently if it were the employee who failed to follow them .... If company policies are not worth the paper on which they are printed, then it would be better not to mislead employees by distributing them..$^{90}$

With the employment handbook standing as an offer, employees' commencement or continuation of work supplies the necessary acceptance and consideration to make a binding unilateral contract. ${ }^{91}$ Whether or not an employee would have continued to work, if a handbook had not been disseminated, is irrelevant. ${ }^{92}$ The only issue under unilateral contract analysis is whether the

(1987) (holding that a handbook was an "offer or promise to hire . . . in return for specified benefits and wages $\left.{ }^{n}\right)$.

${ }^{88}$ See, e.g., Toussaint v. Blue Cross \& Blue Shield, 408 Mich. 579, 619, 292 N.W.2d 880,895 (1980) (stating that guidelines were published and distributed "with a view to obtaining the benefit of improved employee attitudes and behavior and improved quality of the work force"). See generally Coombe, Employee Handbooks: Asset or Liabilily?, 12 EMPLOYEE REL. L.J. 4, 10-13 (1983) (exploring five facets of the employee handbook as an effective management tool: as image builder; communications opportunity; vehicle for establishing rules; problem-solving device; and symbol of security).

${ }^{89}$ See, e.g., Toussaint, 408 Mich. at 619, 292 N.W.2d at 895 (stating that " $[\mathrm{h}$ ]aving announced the policy ... the employer may not treat its promise as illusory").

${ }^{90}$ Small, 292 S.C. at 485, 357 S.E.2d at 454-55 (citations omitted) (quoting Walker v. Westinghouse Elec. Corp., 77 N.C. App. 253, 259, 335 S.E.2d 79, 83 (1985)).

${ }^{91}$ See Pine River State Bank v. Metille, 333 N.W.2d 622, 627 (Minn. 1983); Yartzoff v. Democrat-Herald Publishing Co., 281 Or. 651, 657, 576 P.2d 356, 359 (1978); A. CORBIN, supra note 83, § 63, at 102-03; see also RESTATEMENT (SECOND) OF CONTRACTS, supra note $85, \S 50$ comment b (stating that if an offer invites acceptance by performance, performance creates a contract).

${ }^{92}$ See DeGiuseppe, supra note 18, at 52 \& n.282; cf. Anthony v. Jersey Cent. Power \& Light Co., 51 N.J. Super 139, 143 A.2d 762 (1958) (holding that it is immaterial to the employer's liability whether the employee would have continued in employment in the absence of an offer of severence pay made by the employer). 
promisee executes some minimal level of performance sufficient to furnish consideration. ${ }^{93}$ Any more stringent requirement of "extra" consideration is superfluous.

In their application of unilateral contract theory, progressive courts generally have rejected traditional notions of additional consideration and mutuality of obligation..$^{94}$ By the very nature of a unilateral contract, the consideration for a promise is the actual act or forbearance sought to be induced. An employee beginning or continuing her work furnishes just such consideration. ${ }^{95}$ This analysis is certainly within the "mainstream of contract doctrine," for a detriment (such as work) is sufficient as consideration if bargaining exists. Moreover, "bargaining" means not only negotiations over the exchange of a promise for consideration, but can also mean merely that the promise was made with the intention of inducing the detriment. ${ }^{97}$ Courts have consistently noted that handbooks are distributed for the benefit of the employer. ${ }^{98}$ Handbooks are sources of information which often indicate to the employee that her job is secure so long as she performs competently. By issuing such handbooks, the employer thus induces a more orderly, congenial, and loyal work force. ${ }^{99}$ Additionally, employment handbooks often are issued to induce employees to reject unionization. ${ }^{100}$ Clearly then, employment manuals are not mere gratuities. Instead, they can be reasonably interpreted as offers, promulgated for the employer's advantage, which seek to induce a detriment on the part of employees. Since an employee's work can

93 See, e.g., Helle v. Landmark, Inc., 15 Ohio App. 3d 1, 12, 472 N.E.2d 765, 777 (1984) ("Consequently, when the promisee's performance is executed, enforceable obligations arise without more. Under this analysis, then, appellants continued employment ... rendered the contract to pay severance benefits enforceable, regardless of 'mutuality' or a lack thereof.").

${ }_{94}$ See Note, supra note 25 , at 357 n.99.

${ }^{95}$ See, e.g., Pine River State Bank, 333 N.W.2d at 627 ("The employee's retention of employment constitutes acceptance of the offer of a unilateral contract; by continuing to stay on the job, although free to leave, the employee supplies the necessary consideration for the offer.").

${ }_{96} \mathrm{H}$. PERRITT, supra note 4, at 138.

${ }^{97}$ See id.

98 See sources cited supra note 88.

${ }^{99}$ See, e.g., Toussaint v. Blue Cross \& Blue Shield, 408 Mich. 579, 613, 292 N.W.2d 880,892 (1980) (stating that an employer's announcement of established personnel guidelines "secures an orderly, cooperative, and loyal workforce," and provides "the employee the peace of mind associnted with job security and the conviction that he will be treated fairly"); see also Coombe, supra note 88, at 10-13.

100 See H. PERRIT, supra note 4, at 305-06; Note, Employee Handbooks-Mere Management Guidelines or Enforceabie Contracts?, 18 U. TOL. L. REV. 459, 476 (1987). 
supply the necessary detriment, employment handbooks can logically be viewed as implied contracts.

Unilateral contract analysis also disposes with the traditional obstacle of mutuality. Whereas valid bilateral contracts require each party to be bound by a promise, unilateral contracts do not. Simply put, unilateral contracts are a class of contract exempt from the mutuality of obligation requirement. ${ }^{101}$ The failure to recognize this fact has been a source of confusion to many lawyers ${ }^{102}$ and may account for the at-will doctrine's continued viability in some jurisdictions. Nevertheless, in progressive courtrooms the mutuality of obligation requirement is summarily dismissed as inapplicable to unilateral contracts. ${ }^{103}$ Some progressive courts provide further analysis by asserting that a demand for mutuality of obligation is really nothing more than an inquiry into the adequacy of consideration, an inquiry frowned upon by contract law. ${ }^{104}$ As one court noted, mutuality requirements for a unilateral contract necessitate only a quid pro quo. ${ }^{105}$ Thus interpreted, a unilateral contract lacks mutuality only when there is an absence of consideration. ${ }^{106}$

101 See J. Calamari \& J. Perillo, supra note 84, § 2-10, at 69-71; A. CoRBIN, supra note 83, § 152, at 221-23; RESTATEMENT (SECOND) OF CONTRACTS $\$ 79$ comment $f$ (1979). Some commentators assert that courts still require mutuality but consider the requirement fulfilled by continued employment. See Comment, supra note 58, at 356; Note, supra note 25 , at 357 n.99.

102 See Weiner v. McGraw Hill, Inc., 57 N.Y.2d 458, 463-64, 443 N.E.2d 441, 444, 457 N.Y.S.2d 193, 194 (1982); A. CORBIN, supra note 83, § 21, at 31-32.

${ }^{103}$ See, e.g., Toussaint, 408 Mich. at 600,292 N.W.2d at 885 ("The enforceability of a contract depends ... on consideration and not on mutuality of obligation."); Weiner; 57 N.Y.2d at 464,443 N.E.2d at 444,457 N.Y.S.2d at 196 (dismissing mutuality as unessential to determining the validity of a contract and focusing, instead, on the presence of consideration); Small v. Springs Indus., Inc., 292 S.C. 481, 484, 357 S.E.2d 452,454 (1987) (rejecting appellant's contention that lack of mutuality precluded the existence of an employment contract).

${ }^{104}$ See, e.g., Pine River State Bank v. Mettille, 333 N.W.2d 622, 629 (Minn. 1983) ("The demand for mutuality of obligation ... is simply a species of the forbidden inquiry into the adequacy of consideration, an inquiry in which this court has, by and large, refused to engage."); Blades, supra note 20, at 1419-20 (noting that "mutuality is simply, as many courts have come to recognize, an imperfect way of referring to ... lack of consideration"). Courts have recognized that the detriment to the promisee need not be proportionate to the promise made. They have also recognized that a single and undivided consideration can support any number of promises made by the employer. See Pugh v. See's Candies Inc., 116 Cal. App. 3d 311, 325-26, 171 Cal. Rptr. 917, 924-25 (1981) (quoting Corbin); Weiner, 57 N.Y.2d at 464, 443 N.E.2d at 444, 457 N.Y.S.2d at 197; see also A. CoRBIN, supra note 83, § 125, at 183; RESTATEMENT (SECOND) OF CONTRACTS $\$ 80$ comment a (1979).

${ }^{105}$ See Helle v. Landmark, Inc., 15 Ohio App. 3d 1, 12, 472 N.E.2d 765, 776 (1984); see also Langdon v. Saga Corp., 569 P.2d 524, 527 (Okla. App. 1976).

${ }^{106}$ See Helle, 15 Ohio App. 3d at 12, 472 N.E.2d at 776; Langdon, 569 P.2d at 526-27. 
So long as the employer has induced a detriment from the employee (i.e., work), the employer's promise or promises can be binding.

\section{B. Promissory Estoppel}

Whereas unilateral contract analysis views the employment handbook as an implied contract if the requirements of offer, acceptance, and consideration are met, some courts have made employers' handbooks binding through the use of promissory estoppel. ${ }^{107}$ Whether these courts shrink from unilateral contract analysis $^{108}$ or simply prefer a promissory estoppel approach, ${ }^{109}$ the notion here is that promissory representations reasonably relied upon by the employee estop the employer from reneging on those representations. ${ }^{110}$ This approach eliminates any need to search for offer, acceptance, and consideration. Promissory estoppel does not require bargaining and consideration; instead it seeks to uphold an employee's reasonable reliance upon handbook statements made by the employer. ${ }^{111}$ As with the progressive courts and their utilization of unilateral contract theory, courts applying promissory estoppel are motivated by a desire to avoid inequitable results. ${ }^{112}$ Especially when employees can invest years in a job (accumulating seniority and experience not likely to be transferable to new employment) ${ }^{113}$ or reject alternative job offers, ${ }^{114}$ non-enforce-

${ }^{107}$ See, e.g., Hammond v. North Dakota State Personnel Bd., 345 N.W.2d 359 (N.D. 1984) (relying on estoppel to ensure employer adherence to handbook guidelines); King v. Hosp. Care Corp., No. 1-85-I (Ohio App. May 13, 1986) (WESTLAW, Ohio Courts Database) (holding that the lower court erred in not applying the doctrine of promissory estoppel); Jones v. East Center For Community Mental Health, Inc., 19 Ohio App. 3d 19, 482 N.E.2d 969 (1984) (enforcing representations contained in handbook through estoppel); $c f$. Scholtes v. Signal Delivery Service, 548 F. Supp. 487 (W.D. Ark. 1982) (applying estoppel to an oral employment contract).

${ }^{108}$ See Jones, 19 Ohio App. 3d at 22 n.2, 482 N.E.2d at 973 n.2.

${ }^{109}$ See, e.g., Defrank v. County of Greene, 50 Pa. Commw. 30, 35, 412 A.2d 663, 66667 (1980) (finding estoppel analysis applicable to a claim that the employee's discharge violated the provisions of an employee handbook).

${ }^{110}$ See Note, supra note 100, at 461-62.

111 See Note, supra note 25 , at 371 .

112 See, e.g., Hammond v. North Dakota State Personnel Bd., 345 N.W.2d 359, 361 (N.D. 1984) ("To reject an estoppel here would amount to placing our imprimatur upon an inequitable manipulation of employees' legitimate expectations ...." (quoting DeFrank, $50 \mathrm{~Pa}$. Commw. at 37, 412 A.2d at 667)); Jones v. East Center For Community Mental Health, Inc., 19 Ohio App. 3d 19, 24, 482 N.E.2d 969, 974 (1984) (stating that promissory estoppel "is used to avoid injustice").

113 See Blades, supra note 20, at 1405.

${ }^{114}$ Cf. Grouse v. Group Health. Plan, Inc., 306 N.W.2d 114 (Minn. 1981) (awarding plaintiff damages on promissory estoppel notion after he was induced to quit his job by 
ment of handbook statements seems especially harsh and detrimental to a healthy employment environment. ${ }^{115}$

The Restatement (Second) of Contracts defines promissory estoppel broadly: "A promise which the promisor should reasonably expect to induce action or forbearance on the part of a promisee or a third person and which does induce such action or forbearance is binding if injustice can be avoided only by enforcement of the promise." 116 The definition thus has four requirements. There must, first, be a promise. Second, the promise must be one the promisor should reasonably expect to induce action or forbearance. As one court has noted in the handbook context, the employer's representation is judged by what the "promisor should reasonably expect" the employee to believe the promise means if the expected action or forbearance occurs. ${ }^{117}$ Third, the promisee must actually act or forebear to his detriment. Finally, the promise should be enforced only if injustice otherwise would result.

The principal difference between consideration and promissory reliance is merely that the former is interpreted to be a bargainedfor contractual prerequisite while the latter is unbargained-for. ${ }^{118}$ By resorting to promissory estoppel, judges who do not feel employment manuals represent any sort of bargained-for exchange or who are uncomfortable with finding unilateral contracts may still avoid unjust results. ${ }^{119}$ While the use of promissory estoppel as a substitute for consideration is well recognized, ${ }^{120}$ it should be noted that differences still inhere between unilateral contract analysis and promissory estoppel in their application to employment handbook cases. A primary difference rests in proof. Under

an offer of work which was subsequently retracted).

115 Trust and job satisfaction in the work place have been deemed exceedingly important not only for their intrinsic value but also for their positive impact on productivity. See Bahrami, supra note 36, at 168-71; Farber \& Matheson, supra note 46, at 925-29; Note, supra note 36, at 451-55.

116 RESTATEMENT (SECOND) OF CONTRACTS \$ 90, I 1 (1979).

117 Mers v. Dispatch Printing Co., 19 Ohio St. 3d 100, 105, 483 N.E.2d 150, 154-55 (1984).

${ }^{118}$ See Note, supra note 36 , at 459 (noting that under a promissory estoppel analysis, "unbargained-for reliance frequently is regarded as the equivalent of consideration").

119 See Jones v. East Center for Community Mental Health, Inc., 19 Ohio App. 3d 19, 24, 482 N.E.2d 969, 973-74 (1984) (rejecting appellant's contention that her personnel manual constituted a contract, but holding that the facts of appellant's case did constitute a basis for'promissory estoppel).

120 See Scholtes v. Signal Delivery Serv., Inc., 548 F. Supp. 487, 492 (W.D. Ark. 1982); Morgan, A Comparative Analysis of the Doctrine of Promissory Estoppel in Australia, Great Britain and the United States, 15 MELB. U.L. REV. 134, 148 (1985). 
unilateral contract analysis, an employee's work constitutes consideration. In fact, some courts have presumed that work is consideration for handbook promises even when the employee did not know that the handbook existed. ${ }^{121}$ Under promissory estoppel, however, detrimental reliance can be difficult to prove. ${ }^{122}$ Still another difference between unilateral contract theory and promissory estoppel lies in damages. Under a contract approach, an employee wrongfully discharged in contravention of an employment handbook may recover any damages resulting from the dismissal. Damages under promissory estoppel are limited as justice requires. Moreover, promissory estoppel theoretically limits damages to reliance darnages, ${ }^{123}$ although some scholars have suggested that expectation damages are regularly included in liability assessments. ${ }^{124}$

\section{Unilateral Alterations to Employee HandBooks}

Concerns of fairness and an increasing willingness to examine the employment relationship with approaches "more adopted [sic] to the realities of the workplace" 125 have prompted the majority of states to recognize a handbook exception to the employment-atwill doctrine. ${ }^{126}$ This exception is part of a larger and continuing erosion of the American Rule that increasingly takes into account the rights of employees and the public. ${ }^{127}$ Despite this move-

${ }^{121}$ See, e.g., Toussaint v. Blue Cross \& Blue Shield, 408 Mich. 579, 613-15, 292 N.W.2d 880, 892 (1980) (holding that even where the employee does not know the particulars of the employer's policies, employer statements of policy can give rise to contractual rights in employees without evidence that the parties mutually agreed that the policy statements would create such rights); Woolley v. Hoffmann-La Roche, Inc., 99 N.J. 284, 304, 491 A.2d 1257, 1268 (1985), modified on other grounds, 101 N.J. 10, 499 A.2d 515 (1985) (adopting the analysis of Anthony v. Jersey Cent. Power \& Light Co., 51 N.J. Super. 139, 143 A.2d 762 (1958), that, even without evidence of reliance on an employer's promise, an employee's continued services constituted consideration).

${ }^{122}$ See Farber \& Matheson, supra note 46, at 935.

${ }^{123}$ See Morgan, supra note 120, at 147; Note, supra note 41, at 171.

124 See Farber \& Matheson, supra note 46, at 909.

125 See Comment, supra note 75, at 723.

${ }^{126}$ See cases cited supra note 76.

${ }^{127}$ See, e.g., Blades, supra note 2.0 , at 1412 (discussing state statutes criminalizing an employer's coercion of employees in connection with political activities and the purchase of goods from particular concerns); Note, supra note 27 , at 199 (noting an increasing willingness among states to grant exceptions to the at-will doctrine); Note, supra note 25, at 342-43 (discussing the limitation on the employment-at-will doctrine as found in the Railway Labor Act of 1926, the National Labor Relations Act, and Title VII of the Civil Rights Act); supra notes 34-35 and accompanying text. 
ment's modifications in the context of the handbook exception, one consistent and potentially troublesome caveat accompanies nearly all the decisions made in this area-even the decisions of progressive courts applying unilateral contract theory or promissory estoppel. This troubling caveat is the concession made by courts that, although an employer's handbook can be found to create binding promises, an employer may subsequently unilaterally change that handbook so as to discontinue her duties under it. ${ }^{128}$ For reasons of both contract law and equity, this Comment argues that such unilateral emendations should not be permitted.

Handbooks contain promises covering topics ranging from justcause provisions and procedures for dismissal, to seniority, lay-offs, and vacation benefits. As explained above, ${ }^{129}$ these handbook promises can be legally enforceable. The handbook, in this sense, becomes a "Bill of Rights" for employees. Employers, however, often re-issue newer editions of handbooks that excise previous statements and procedures. Frequently, disclaimers are added, describing the handbook as a mere guideline, capable of being changed at any time. ${ }^{130}$ By stating that the handbook does not in any way constitute the terms of an employment contract ${ }^{131}$ these disclaimers attempt to provide the manuals with blanket insulation from liability. ${ }^{132}$ While the courts do show a willingness to

${ }^{128}$ Progressive courts, while often carving out an exception to the at-will rule by finding implied contracts through handbooks, have, in dicta, also sanctioned employer's unilateral changes to the handbooks. See, e.g., Toussaint v. Blue Cross \& Blue Shield, 408 Mich. 579, 613-15, 292 N.W.2d 880, 892 (1980) (stating that, while handbooks may constitute unilateral contracts, employers retain the ability to modify these handbooks unilaterally); Pine River State Bank v. Mettille, 333 N.W.2d 622, 627 (Minn. 1983) (noting that statements of policy can be unilaterally amended by the employer without notice to the employee).

${ }^{129}$ See supra notes 78-124 and accompanying text.

${ }^{190}$ See, e.g., Chambers v. Valley Nat'l Bank, 721 F. Supp. 1128, 1131 (D. Ariz. 1988) (holding that, where the employer added a disclaimer to a handbook 14 years after plaintiff was hired, the employee could not rely on the handbook to demonstrate that the employment was not at-will).

131 See id.

${ }^{132}$ The effect of disclaimers in original or amended handbooks is unpredictable, varying with jurisdiction and the facts of each case. See Note, The Use of Disclaimers to Avoid Employer Liability Under Employee Handbook Provisions, 12 J. CORP. L. 105, 112-15 (1986). The author of that note suggests that '[ $r$ ather than searching for the 'perfect' disclaimer," management should instead concentrate on issuing carefully conceived handbooks by which it is willing to abide. See id. at 120; see also Jones v. Central Peninsula Gen. Hosp., 779 P.2d 783,788 (Alaska 1989) (rejecting a handbook disclaimer because 85 pages of the handbook created an impression contrary to the one sentence disclaimer). 
protect employees' accrued rights (such as seniority, severance pay, and, in some aspects, vacation) from subsequent unilateral changes, ${ }^{133}$ the potential for an employer to retract promises or to distribute a new handbook which is inconsistent with a former edition is disturbing.

\section{A. The Argument for Allowing Unilateral Changes by Employers}

The primary reason why many courts seem willing to allow unilateral changes to handbooks is that such changes appear to be countenanced by unilateral contract analysis itself. If an employer's handbook is specific enough to constitute an offer and if an employee's commencement or continuation of work constitutes acceptance and consideration, ${ }^{134}$ logically, by continuing to work after the issuance of an amended handbook, the employee has once again bound herself and the employer to the new handbook. ${ }^{135}$ As one court concisely summed, "[i]f [the employer] chooses to modify its existing policies, a new unilateral contract is offered, and an employee can signify acceptance by remaining on the job."136

Another, non-contractual reason for permitting unilateral changes, advanced by at least one court, is that such changes injure the employer just as they injure the employee. ${ }^{137}$ Since the

${ }^{133}$ See, e.g., Gilman v. County of Cheshire, 493 A.2d 485, 489 (N.H. 1985) (holding that while employers may modify terms of employment, rights which have vested under previous terms of employment are not subject to modification); Helle v. Landmark, Inc., 15 Ohio App. 3d 1, 472 N.E.2d 765, 775 (1984) (holding that, where oral assurances of severance pay conflicted with the employment manual's disclaimers or induced employees to disregard their significance, the assurances negate the disclaimers thereby absolving the employer from liability for unilateral alterations in the written manual); Langdon v. Saga Corp., 569 P.2d 5\%4, 527 (Okla. Ct. App. 1976) (stating that where an at-will employee performs in reliance on the employer's articulated personnel policies, the employer may modify those policies, but remains bound to them insofar as they have accrued to an employee for performance rendered).

${ }^{134}$ See supra text accompanying notes 87-92.

135 See, e.g., Chambers v. Valley' Nat'l Bank, 721 F. Supp. 1128, 1131-32 (D. Ariz. 1988) (stating that the employer's inclusion of a disclaimer in a handbook published subsequent to plaintiff's employment constituted an offer to modify a unilateral contract of employment, which the plaintiff accepted by continuing her employment); Pine River State Bank v. Mettille, 333 N.W.2d 622, 627 (Minn. 1983) (stating that employment contracts may be modified or replaced by a subsequent unilateral contract, with the employee's continued employment signifying acceptance); Brookshaw v. South St. Paul Feed, Inc., 381 N.W.2d 33, 36 (Minn. Ct. App. 1986) (stating that if an employer modifies existing policies, a new unilateral contract is offered which the employee accepts by remaining on the job).

${ }_{136}$ Brookshaw, 381 N.W.2d at 36.

${ }^{197}$ See Bankey v. Storer Broadcasting Co., 432 Mich. 438, 454, 443 N.W.2d 112, 119 
employer distributes the original handbook seeking to secure good will and increased productivity, any subsequent denial of employee privileges and rights diminishes the employer's benefit. ${ }^{138} \mathrm{Be}-$ cause the employer is also injured, there is thus a strong disincentive for employers to alter their handbooks in ways adverse to their employees; theoretically, employers would only change their manuals when absolutely necessary.

Closely linked to this notion of mutual injury is the suggestion that an employer, as the manager of the business venture, should retain the flexibility and latitude necessary to operate the business as she sees fit; indeed this idea underlies much of the argument in favor of unilateral modification. ${ }^{139}$ Company policies, including those in an employment handbook, are not static. To hold that handbooks contain immutable rights would mean that policies "could never be changed short of successful renegotiation with each employee who worked while the policy was in effect." 140 Holdouts and logistical problems could thus result in a patchwork of employment arrangements across a work force. This argument suggests that uniformity of contract would disappear and the employer would find herself obligated in a variety of ways to different groups of employees depending upon the handbook they were hired under and what modifications they had accepted. ${ }^{141}$

While most courts that uphold unilateral changes to employment manuals do require that adequate notice be given to all affected employees, ${ }^{142}$ principles of contract law and reasons of policy suggest to many courts that unilateral changes in subsequent manuals-even when inconsistent with policies established in the former handbook-are legitimately enforceable.

\section{B. The Argument Against Allowing Unilateral Changes by Employers}

While only a handful of jurisdictions have considered the issue of unilateral modifications to employment manuals, an even smaller number of courts have suggested that such alterations are not

(1989).

${ }^{138}$ See id.

${ }^{139}$ See id. at 456, 443 N.W.2d at 120.

${ }^{140} I d$.

141 See id.

142 See id. at 457,443 N.W.2d at 120 . But see Toussaint v. Blue Cross \& Blue Shield, 408 Mich. 579, 615, 292 N.W.2d 880, 892 (1980). 
automatically binding. ${ }^{143}$ Nevertheless, the arguments that can be advanced for this latter position are compelling.

As a matter of jurisprudence, many of the decisions upholding unilateral modification cite with approval "precedent" which does not even involve the issue of alterations to handbooks. ${ }^{144}$ While many of the seminal cases concerning the issue of whether handbooks could ever be implied contracts did incidentally claim that employers could subsequently modify such manuals, these statements were made with little to no analysis since they were not essential to the holding of the case sub judice. ${ }^{145}$ Such dicta should not provide authority for the cases permitting modification.

More substantively, decisions permitting unilateral modification are "inconsistent with general contract law"146 and in fact "run contrary to established principles of contract formation." ${ }^{147}$ This is primarily because the employer is legally bound by the terms of the promises made in the prior handbook; ${ }^{148}$ she cannot thereafter unilaterally amend the conditions of that implied contract. ${ }^{149}$ As Professor Corbin asserts, "the employer's offered promise becomes irrevocable by [the employer] as soon as the employee has rendered any substantial service in the process of accepting; and this is true in spite of the fact that the ernployee may be privileged to quit the service at any time." 150

143 See, e.g., Toth v. Square D Co., 712 F. Supp. 1231, 1255 (D.S.C. 1989) (holding that an employee's contractual rights are not altered by distribution of new handbooks unless the employee consented to the modification and received consideration); Thompson v. Kings Entertainment: Co., 653 F. Supp. 871, 875 (E.D. Va. 1987) (holding that unilateral amendments to a handbook are not automatically effective upon issuance of the second handbook); King v. Hospital Care Corp., No. 1-85-1 (Ohio App., May 13, 1986) (WESTLAW, Ohio Courts Database) (holding that an employer could not unilaterally modify the terms of a handbook-created contract); Helle v. Landmark, Inc., 15 Ohio App. 3d 1, 11-12, 472 N.E.2d 765, 776-77 (1984) (holding that handbook alterations are not binding unless the employee consented to modification and received consideration).

${ }^{144}$ See, e.g., Chambers v. Valley Nat'l Bank, 721 F. Supp. 1128, 1131-32 (D. Ariz. 1988) (citing Pine River State Bank v. Mettille, 33 N.W.2d 622, 626-27 (Minn. 1983)); Brookshaw v. South St. Paul Feed, Inc., 381 N.W.2d 33, 36 (Minn. Ct. App. 1986) (same).

${ }^{145}$ See Toussaint, 292 N.W.2d at 892; Pine River State Bank v. Mettille, 333 N.W.2d 622, 627 (Minn. 1983).

146 Thompson, 653 F. Supp. at 876.

147 Toth, 712 F. Supp. at 1235.

148 See id.

149 See King v. Hospital Care Corp., No. 1-85-1 (Ohio App., May 13, 1986) (WESTLAW, Ohio Courts Databaise).

${ }^{150} \mathrm{~A}$. CORBIN, supra note $83, \S 153$, at 224 . 
It must be recognized and emphasized that issuing a second, unilaterally modified handbook is not the same as issuing the first. The employer who issues a second handbook is not taking the employee out of an at-will situation by offering her an implied contract. Instead, the second handbook constitutes an offer to modify the existing implied contract. While such an offer may be accepted, an amended handbook does not become effective automatically upon issuance by the employer and continuation of work by the employee. ${ }^{151}$ Rather, the traditional requirements of contract modification-assent to modify and additional consideration (here from the employer)-must be met. ${ }^{152}$ The reason that the requirement of additional consideration here is dissimilar to the simple work requirement necessary under the unilateral contract analysis for the original handbook lies in the differing contexts. With a first edition handbook, an employee must act to accept the employer's offer embodied in the manual. However, an employee need not act to reject a subsequent modified handbook. The employee already enjoys an enforceable implied contract. Only an acceptance requires affirmative action in the form of performance. ${ }^{153}$ As one court asserted, "Requiring an offeree to take affirmative steps to reject an offer . . . is inconsistent with general contract law .... The offeree need make no reply to the offer"154 and her silence does not imply assent. ${ }^{155}$ Accordingly, it is not incumbent upon the employee to give specific notice of rejection. Moreover, the mere fact that an employee continues to work does not constitute acceptance of the unilaterally altered employment manual. ${ }^{156}$ Whether employees do accept the offered modification of a revised handbook is thus a question of fact for a jury in its assessment of assent and consideration. ${ }^{157}$ Assumptions by some courts that continued work by the employee automatically makes the amended handbook binding are contrary to established principals of contract law. 1987).

151 See Thompson v. Kings Entertainment Co., 653 F. Supp. 871, 875-76 (E.D. Va.

${ }^{152}$ See Toth v. Square D Co., 712 F. Supp. 1231, 1235-36 (D.S.C. 1989); Thompson, 653 F. Supp. at 875-76; see also $15 \mathrm{~S}$. WILLISTON, TREATISE ON THE LAW OF CONTRACTS $\S 1829$ (3d ed. 1957 \& Supp. 1990).

153 See $1 \mathrm{~S}$. WILLISTON, supra note $152, \S 91$.

154 Thompson, 653 F. Supp. at 876.

${ }^{155}$ See id.

${ }^{156}$ See id.

${ }^{157}$ See Toth v. Square D. Co., 712 F. Supp. 1231, 1236 (D.S.C. 1989). 
It is interesting to note that the above interpretation is entirely consistent with the "freedom of contract" doctrine which once buttressed the venerable at-will rule. ${ }^{158}$ Freedom of contract permits all parties to contract as they see fit. If employers are willing to agree to employment on particular terms for an unspecified duration, then the handbook allows them to do so. ${ }^{159}$ Yet once that contract is made it should be respected. Employers should be held to their promises. This simple respect for the integrity of the handbook-created contract will guard against the temptation for employers to promise at one moment what they could just as easily take away at the next. ${ }^{160}$ The policy which underlies the original handbook exception to the at-will doctrine-the protection of employees from the inequities of illusory promises held out to them-is thus just as persuasive in the unilateral alteration context. For if "[i]t is patently unjust to allow an employer to couch a handbook, bulletin, or other similar material in mandatory terms and then allow [the employer] to ignore these very policies as ' $a$ gratuitous non-binding statement of general policy' whenever it works to [the employer's] disadvantage"; ${ }^{161}$ the same logic must apply to unilateral changes. Clearly, it would be nearly as easy for the employer to change her handbook as to "ignore" it. As one court has noted, "[i]f an employer were permitted to extinguish an employee's rights under an existing handbook through the simple expedient of a revised handbook, employees could suffer the very inequities the [handbook exception] court sought to prevent."162 Indeed, if the cases which interpret handbooks as contracts stand for one proposition, it is the notion that employer representations relating to substantive rights and duties can be binding. Giving legal force to unilateral changes to handbooks, however, does serious damage to this notion.

Closely aligned with the principle that the employment handbook has contractual integrity is the proposition that handbooks should be enforceable by employees who have relied on their promises. For example, employees who join companies with just

${ }^{158}$ See H. PERRITT, supra note 4, at 4-5.

${ }^{159}$ See Helle v. Landmark, Inc., 15 Ohio App. 3d 1, 7, 472 N.E.2d 765, 772 (1984); Note, supra note 25, at 368-69.

${ }_{160}$ See Thompson v. Kings Entertainment Co., 653 F. Supp. 871,875 (E.D. Va. 1987).

${ }^{161}$ Toth, 712 F. Supp. at 1235 (quoting Small v. Springs Indus., Inc., 292 S.C. 481, 485-86, 357 S.E.2d 452, 454-55 (1987)).

${ }^{162} I d$. 
cause provisions in their handbooks come to rely on such statements. It is grossly unjust to tell an employee who has been working for years under such a provision that the handbook has suddenly been changed. Such a change can have great impact on an employee who previously could be fired only for good cause. Unfortunately, it cannot be presumed that such a change is an innocuous one for the competent employee. In fact, case histories indicate that satisfactory employees of long service are often fired soon after such alterations to employee handbooks. ${ }^{163}$ The fairness which employees who have relied on employment manual statements deserve-in essence the principle of promissory estoppel-further enhances the desirability of respecting the original handbook agreement.

Courts that have been quick to deny any contractual obstacles to allowing a revised employment manual to replace a former edition have been given cause to hesitate over promissory estoppel concerns. ${ }^{164}$ In fact, while one state supreme court held that employers may unilaterally change their written policies concerning just cause provisions in their handbooks, it also included an opinion which warned that if "the court determines that legitimate expectations of job security arose before the change in policy from discharge-for-cause to termination-at-will, the court should provide a remedy." 165 It seems clear that any court willing to use promissory estoppel to give force to employer promises in the context of an original handbook should also be willing, de facto, to apply the doctrine to estop an amended handbook.

Other arguments supporting the unilateral amendment of employment manuals seem insubstantial or speculative. The concern for uniformity of contracts across a work force appears insignificant compared to the contractual or equitable rights employees retain under unilateral contract or promissory estoppel analyses. Furthermore, such a concern may be more hypothetical than real. Corporations frequently employ unionized and non-

${ }^{163}$ See, e.g., Chambers v. Valley Nat'l Bank, 721 F. Supp. 1128, 1131 (D. Ariz. 1988) (noting that an employee with fourteen years of service was fired soon after a just cause handbook was disclaimed); King v. Hosp. Care Corp., No. 1-85-1 (Ohio App. May 13, 1986) (WESTLAW, Ohio Courts Database) (noting that an employer added a disclaimer to a handbook with just cause provisions and soon thereafter fired an eighteen-yearemployee).

${ }_{164}$ See Bankey v. Storer Broadcasting Co., 432 Mich. 438, 459-61, 443 N.W.2d 112, 121-22 (1989) (Levin, J., separate opinion).

$165 \mathrm{Id}$. 
unionized, as well as contract and at-will employees. ${ }^{166}$ Moreover, employers will have little difficulty amending handbooks to the advantage of employees. The assent and consideration necessary to give effect to beneficial modifications to the former handbook should pose no problem. Only when the employer is attempting to alter the handbook to the detriment of the employee will she encounter resistance.

Far from spawning a multitude of handbook contracts, a respect (judicially enforced or otherwise) for the terms embodied in the original handbook may create uniformity. Variations in handbook terms across a work force can create dissension and reduce productivity. Additionally, potential employees may be reluctant to join a firm if employees working under former handbooks enjoy better benefits. Because of such potential disparity and the ease with which employers could improve handbook packages, a judicial presumption against unilateral modification of employment manuals would retard unfair amendments and tend to enhance the incentive for employers to offer one attractive employment manual to both present and future employees.

Concerns for managerial flexibility seem equally ill-founded. This Comment argues against any rationale that suggests unilateral modifications to handbooks are automatically binding on employees who continue to work. This is not to state that minor changes could never be made to a handbook or that major amendments could never be offered and accepted. Respect for the employee handbook as a contract simply implies duties akin to those arising from a covenant of good faith and fair dealing. ${ }^{167}$ Such a restriction would merely prevent the employer from making substantive changes counter to the spirit of the handbook contract unless she provides consideration and the employee assents. Absent exigent business circumstances, ${ }^{168}$ interests in protecting the integrity of

166 See R. FREEMAN \& J. MEdofF, What Do Unions Do? 34 (1984).

${ }^{167}$ See Fortune v. National Cash Register Co., 373 Mass. 96, 364 N.E.2d 1251 (1977); Monge v. Beebe Rubber Co., 114 N.H. 130, 316 A.2d 549 (1974). See generally Madison, The Employee's Emerging Right to Sue for Arbitrary or Unfair Discharge, 6 EMP. REL. L.J. 422, 426-35 (1980-81) (discussing covenants of good faith and fair dealing in the employment context).

${ }^{168}$ See Linn v. Beneficial Commercial Corp., 226 N.J. Super. 74, 543 A.2d 954 (1988) (holding that an action does not lie for wrongful discharge where loss of work was a result of the elimination of a job itself due to legitimate economic factors, even where the eliminated employee enjoyed a "just cause" clause stated in a personnel manual); see also Woolley v. Hoffmann-La Roche, Inc., 99 N.J. 284, 300-01, 491 A.2d 1257, 1266 \& n.8 (1985) (explaining that a contract arising from an employment manual may be 
the original handbook contract and employee interests make it only fair that the traditional prerequisites of contract modification be observed.

\section{CONCLUSION}

Because handbook modification is not analogous to the issuance of an original handbook, legal principles pertaining to contractual formation and the handbook are inapposite. Instead, employer alteration of handbooks must be assessed against the modification prerequisites of assent and consideration as outlined here. Assent and consideration are issues of fact for a jury which must be explored within the context of each case. Additionally, notions of reliance and promissory estoppel should be considered as factors relevant to the unilateral alteration of employment manuals.

The above approach, while admittedly making it more difficult for management to alter the handbook relationship with its employees, will not make alteration impossible. Consequently, managerial flexibility will not ossify. Whatever the speculative and limiting effects such an approach may have, it seems only appropriate that the employer, having freely written and proffered the handbook to her employees, should be bound by the terms of the original document.

terminated when business circumstances so require), modified on other grounds, 101 N.J. 10,499 A.2d 515 (1985). Certainly even employees working under handbooks with just cause provisions may be terminated under exigent business circumstances. Reductions in force as well as technological advances may necessitate some firings. However, this Comment contemplates only business exigencies-not mere expedience-as valid reasons for the discharge of employees counter to the terms of an employment handbook. 
